\title{
Potential usage of Beneish's M-score under the conditions of selected segment of Slovak Economy
}

\author{
Boris Kollar ${ }^{1, *}$ \\ ${ }^{1}$ University of Zilina, Faculty of Operation and Economics of Transport and Communications, \\ Univerzitna 1, 01026 Zilina, Slovakia
}

\begin{abstract}
Research background: The motivation behind submitted article is the institutional research of earnings management. The aim is to identify the differences between the usage of creative accounting techniques in the form of Beneish's M-score under the conditions of Slovak economy. The paper focuses on these differences and specifics and possible reasons behind them. Paper highlights also the impact of globalization on companies and therefore also behind their motives to use earnings management. It also offers several definitions of earnings management and also highlights the importance of the borderline knowledge between earnings management and fraudulent behavior. The Beneish's model seems to be used by several of major Slovak companies in food segment. The aim was to analyse this sector of Slovak economy, because of its importance to everyday life of people. To assess the motivation behind its usage by these companies. Either it is because they want to transfer their earnings to maternal companies, or there are unexpected local circumstances.

Purpose of the article: To describe specifics in the process of Beneish's model usage under the conditions of selected segment of Slovak economy and also to highlight motivation behind its usage.

Methods: The paper is built on the statistical methods, financial analysis as well as the methods of formal logic, like comparison, analysis or synthesis and deduction.

Findings \& Value added: Comprehensive overview of the earnings management definition, its forms and motives behind its usage and foremost specifics in its usage under the conditions of selected segments of Slovak economy.
\end{abstract}

Keywords: earnings management; Beneish's M-score; globalization; financial statements; motivation

JEL Classification: $G 10 ; G 20 ; O 10$

\footnotetext{
${ }^{*}$ Corresponding author: boris.kollar@gfpedas.uniza.sk
} 


\section{Introduction}

Earnings management, is an area interesting for every businessman or manager in the company. Profit or loss reflects the performance of companies and their success as such, which are targeted not only by internal employees but also by other external entities, e.g., new investors, banks, suppliers. The reported profit of companies can be influenced to some extent. Managers in companies strive for this when the uncontrollable part of the profit does not meet the required amount expected by shareholders or which was specified in the contract.

The term "management" can be understood in different ways, for example, according to prof. Farmer's, management means a practical activity, a theory, or a scientific discipline, or even a special group of people (Sedlak, 1997). We will look at this concept as a way of managing, administering or controlling people in order to achieve pre-seted goals. Proper set up of management plays an important role in a company, because it greatly influences whether a pre-seted goal can be met. The term "earnings management" was used for the first time in history in 1994 by Hepworth. Defining this concept with a simple sentence is difficult, as it follows from its nature, but for the purposes of this paper, we have decided start with following definition: Earnings management is meant to mislead shareholders about the underlying economic performance of companies or to influence contractual results that depend on reported accounting numbers (Healy, Wahlen, 1999). The above-mentioned definition may at first sight evoke that this is only a nicer name for fraud in the accounting sphere, but the opposite is true. Earnings management uses only legal methods without violating the accounting rules, ie without being in breach of the law, and therefore cannot be described as fraudulent (Connolly-Barker, et al., 2020). Thanks to the accounting policy, managers have a certain space and the opportunity to apply the principles of earnings management (Vagner et al., 2021).

While applying earnings management in their respective companies, their managers should not forget which forms of these adjustments are still acceptable from the legislation point of view and which adjustments could already be considered illegal. Either Generally Accapted Accounting Principles - US GAAP6 (an accounting standards, which main purpose is to provide uniform rules, standards and conditions for the preparation of financial statements for all enterprises is used as a base for United States) or the European Accounting Standards, which are base in Europe - IAS-IFRS (International Accounting Standards and International Financial Reporting Standards, which are mandatory in European Union since 2005 in order to ensure better and easier comparability and transparency7)(Management mania, 2015). Non-discretionary accruals are presented to management from GAAP / IFRS and they can manage revenue in discretionary accruals, because they have the flexibility to manage accounting decisions (Strakova, Michalkova, 2020).

The reported profit consists of two parts. Namely controllable and uncontrollable profit. They are directly connected with two situations, that can influence the decision of the company o se earnings management (Clark et al., 2020). The first situation is tied with unpredictable profit. Its value is expected to be different from the goal set up by management. It is either too low, and managers try to increase it, or too high and managers try to reduce its value. The specifically of the goal may be based on the expectations of the shareholders themselves or by the base of an agreement, which is stated in the concluded agreement. In the second situation, managers gain some bonuses from the profit adjustments in order to attract more interest from the shareholders (Popescu, Olah 2020; Siekelova et al., 2020).

Earnings management is often associated with market competition and market power. Datta et al., in their work, found out that companies with low market power have a low ability to increase the prices of their products, when their costs start to rise and they are not able to pass these costs on to consumers (Datta et al., 2011). This is one of the reasons why companies are more likely to apply earnings management. Many companies use it to reduce 
revenue fluctuations, so they can more accurately determine its actual profit for a certain period (quarter, half year, year) (Tuovila, 2020). Although fluctuations in income and expenditure are common, they are a deterrent to investors. It is ideal for them to see that the state of the company is stable, at best it is constantly improving. For this reason, managers are under pressure. Their goal is to retain investors and increase the value of the company's shares, which creates room for certain manipulations of earnings. As an example, we will mention the situation when a furniture company changes its accounting policy so its reported profit is higher. It achieves this by using the LIFO method (last in, last out) to assess the consumption of stocks, but after the change it started using the FIFO method (first in, first out). Like this, the company first consumes the items which entered first. As inventory costs tend to increase over time, with the LIFO method, newly purchased inventories go into consumption first, so the cost of the product is higher and this reduces profits (Kliestik et al., 2020). However, thanks to the FIFO method, the cost of the product sold is lower, which increases the calculated profit (Savova, 2021).

\section{Methods}

Taking into account Slovakia and the necessary inputs for the calculation of earnings management. We have decided to use the Beneish model for the purpose of this paper. Mr. Beneish, the author of this model created a model by which we can recognize the presence and application of earnings management in the company (Beneish, 2019). He achieved this goal with the use of 8 financial ratios, which are the base for the final M-score calculation as follows:

$$
\begin{gathered}
\mathrm{M}=-4,84+0,92 * \mathrm{DSRI}+0,528 * \mathrm{GMI}+0,404 * \mathrm{AQI}+0,892 * \mathrm{SGI}+0,115 \\
* \mathrm{DEPI}-0,172 * \mathrm{SGAI}+4,679 * \mathrm{TATA}-0,327 * \mathrm{LVGI}
\end{gathered}
$$

The variables listed in the formula 1 above contain data from the financial statements, specifically from all its parts (balance sheet, profit and loss statement, notes).

DSRI (Days Sales in Receivables) is the ratio of receivables and sales at time t, which is set to the ratio of the same variables at time $t-1$. If the value of DSRI $>1$, the company's receivables increase year-on-year as a percentage. It means that the company has a higher percentage of debtors each year, from which it expects income for goods or services sold in the future.

The GMI (Gross Margin Index) compares the gross margin of period t-1 to the gross margin of period t. It is favourable for the company if the index shows a value lower than 1 . On the contrary, if the value is above 1 , there is a high probability of income manipulation according to financial researches.

AQI (Asset Quality Index) measures the ratio of values in period $t$ and $t-1$. The values consist of non-current assets reduced by tangible fixed assets in relation to total assets. If AQI $>1$, the company's non-current assets without tangible fixed assets increase year-on-year by more than the total assets.

SGI (Sales Growth Index) puts in the ratio, the sales from business activities of the period $\mathrm{t}$ and $\mathrm{t}-1$. The higher is the value above 1 , the higher is percentage increase in year-on-year sales.

The DEPI (Depreciation Index) shows the ratio of variables from period $t-1$ to $t$, which consists of the ratio of depreciation and tangible fixed assets plus depreciation. If DEPI $>1$, the effective depreciation rate of the company has slowed down in year-on-year comparison, and the higher is the value, the more the depreciation rate decreases.

The SGAI (Sales and General and Administrative expenses Index) takes into account the cost of economic activity and sales from period $t$, which it compares with the previous period. 
Again, if the value is higher than 1, the costs of economic activity grew faster than the growth of sales.

TATA (Total Accruals to Total Assets) measures the ratio of net profit lowered by cash flow to total assets ratio.

The LVGI (Leverage Index) compares the ratio of interest-bearing sources of funding to assets in the current period with the previous one. As the LVGI value increases, so does the strength of the leverage effect.

After Beneish model application, we get the value $\mathrm{M}$ as a result. If $\mathrm{M}>-2.22$, the company uses EM.

For the purposes of our paper, we have decided to focus on companies in selected industry of Slovak economy. The final decision fell on the food industry, because of its importance to everyday life. We selected the sample of 5 most important companies in the industry. Namely BILLA s. r. o., COOP Jednota Slovensko, spotrebné družstvo, Kaufland Slovenská republika v.o.s., Lidl Slovenská republika, v.o.s., TESCO STORES SR, a.s., and we drew the necessary data from the Finstat portal, which provided us with the financial statements of selected companies from 2009 to 2019 for the purposes of the paper.

In order to calculate the Beneish M-score correctly, it is necessary to calculate the basic 8- financial-ratio indicators mentioned above as one of the first steps. Therefore, we created a table that contains the several data. Namely sales, receivables, costs of goods sold, current assets, tangible fixed assets, assets, depreciation, long-term liabilities, costs of economic activity, net profit, cash flow, liabilities. There were several barriers in the process of Mscore calculation, because some of the needed values were missing from different reasons. Either the company did not exist or there was some kind of restructuring process. Similar problem also occurred for authors of other studies like (Kliestik et al., 2020).

\section{Results and Discussion}

In the calculation of the value of $M$ itself, the results of which are shown in Table 1, we observe that in $55 \%$ of cases the final value was higher than -2.22 , therefore we can talk about the situation when the company used earnings management to adjust the financial statements. During one of the analysed years, the company BILLA, s.r.o. has reached a threshold, so it is not possible to determine whether the probability of using earnings management is valid or not. In the case of Kaufland, v.o.s., we can observe a sharp increase in the M-score in 2013. After closer look to input data, we assigned this to the high value of AGI and LVGI variables. We can also state that all monitored companies used earnings management for at least some time during our observed 10-year period. These earnings procedures are most often used by Kaufland, v.o.s., followed by Lidl, v.o.s. On the contrary, company Billa, s.r.o. did not apply earnings management for more than two of the observed periods.

Table 1. M-score calculation.

\begin{tabular}{|l|r|r|r|r|r|r|r|r|r|r|}
\hline M-score & $\mathbf{2 0 1 0}$ & $\mathbf{2 0 1 1}$ & $\mathbf{2 0 1 2}$ & $\mathbf{2 0 1 3}$ & $\mathbf{2 0 1 4}$ & $\mathbf{2 0 1 5}$ & $\mathbf{2 0 1 6}$ & $\mathbf{2 0 1 7}$ & $\mathbf{2 0 1 8}$ & $\mathbf{2 0 1 9}$ \\
\hline BILLA & $-1,735$ & $-2,422$ & $-2,220$ & $-2,390$ & $-2,379$ & $-2,246$ & $-2,433$ & $-2,755$ & $-2,127$ & $-2,706$ \\
\hline COOP & $-2,211$ & 9,817 & $-2,269$ & $-2,008$ & $-2,549$ & $-2,773$ & $-2,348$ & $-2,332$ & $-2,020$ & $-2,170$ \\
\hline Kaufland & $-2,131$ & $-2,752$ & 0,179 & 17,766 & $-2,213$ & $-1,964$ & $-2,031$ & $-2,163$ & $-1,184$ & $-2,486$ \\
\hline Lidl & NA & $-2,744$ & $-1,156$ & $-2,339$ & $-1,546$ & $-1,028$ & $-1,852$ & 0,467 & $-1,902$ & $-1,912$ \\
\hline TESCO & $-3,197$ & $-3,138$ & $-1,787$ & $-2,533$ & $-1,846$ & $-1,798$ & $-2,615$ & 0,430 & $-2,638$ & $-2,133$ \\
\hline
\end{tabular}

Source: own processing 
We have to also underline, that there is not a single year in which all 5 companies achieve the same state of earnings management application. This may lead to the conclusion that there are no external adverse circumstances, that would affect the global functioning of the entire food industry and therefore cause efforts to manipulate their earnings by companies. To be able to make a comparison over certain time period, it was necessary to correctly classify the values of the M-score on the basis of specific companies and years. We decided to use a graphic representation for transparent processing and reflection of time development.

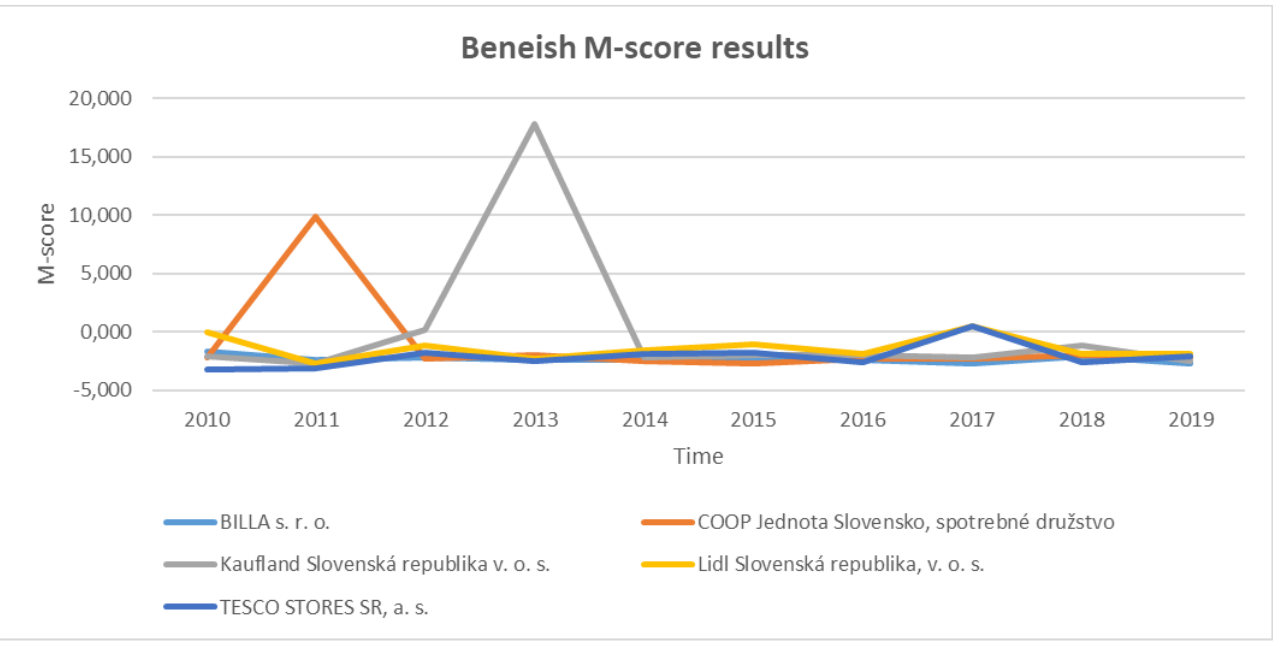

Figure 1. Beneish M-score results.

Source: own processing

On the figure 1 we can see, that the value of M-score has fluctuated over the years without large deviations, but in 2011 COOP Jednota and Kaufland Slovenská republika in 2013 have reached very surprising values. They climbed up to extreme value of 5. Later, in 2017, Lidl Slovenská republika and TESCO STORES SR, had reached positive values, but not such extremes.

Table 2. Setting Word's margins.

\begin{tabular}{|l|r|}
\hline$(-\infty ;-2,5>$ & 11 \\
\hline$(-2,5 ;-1,5>$ & 30 \\
\hline$(0 ; 1,5>$ & 3 \\
\hline$(0 ; 5>$ & 3 \\
\hline$(5 ; 20>$ & 2 \\
\hline Sum & 49 \\
\hline
\end{tabular}

\begin{tabular}{|l|r|r|}
\hline$(-2,5 ;-2,22)$ & 10 & $33 \%$ \\
\hline$(2,22 ;-1,5>$ & 19 & $63 \%$ \\
\hline$-2,22$ & 1 & $3 \%$ \\
\hline Sum & 30 & $100 \%$ \\
\hline
\end{tabular}

Source: own processing

Table 2 depicts intervals in which the individual values are located. Most values reach a value in the range from -2.5 to -1.5 . Up to $63 \%$ of the values are from this interval. Companies from this interval can be therefore identified as earnings managers users. Earnings management represents a legally acceptable adjustment of financial statements by companies according to legal principles accepted by Slovak republic. 


\section{Conclusion}

One of the aims of this paper was to analysed theoretical approaches, concepts and methods of earnings management application under the conditions of Slovak republic. After this analysis, we decided to use Beneish's model, because of its build up and usability in our country. Subsequently, we applied Beneish's model in selected segment of Slovak economy. We chose food industry, because of its importance for every day life. Based on the obtained results, we can say, that earnings management is used by companies in food industry. However, we were unable to determine deeper motivation behind its usage. We consider the usage of Beneishe's model to be helpful, but to understand all motivations behind it and to understand financial situation of the company, it should be used as a part of complex financial analysis process. On this part we agree with authors of similar studies like (Durana et al., 2021).

\section{Acknowledgements}

The paper is an output of the science project VEGA 1/0210/19 Research of innovative attributes of quantitative and qualitative fundaments of the opportunistic earnings modelling which authors gratefully acknowledge.

\section{References}

1. Beneish, M. D. (2019). The Detection of Earnings Manipulation. Financial Analysts Journal, 55(5), 24-36.

2. Clark, A., Zhuravleva, N. A., Siekelova, A, \& Frajtova Michalikova, K. (2020). Industrial Artificial Intelligence, Business Process Optimization, and Big Data-driven Decision-Making Processes in Cyber-Physical System-based Smart Factories. Journal of Self-Governance and Management Economics, 8(2), 28-34.

3. Connolly-Barker, M., Gregova, E., Dengov, V. V., \& Podhorska, I. (2020). Internet of Things Sensing Networks, Deep Learning-enabled Smart Process Planning, and Big Data-driven Innovation in Cyber-Physical System-based Manufacturing. Economics, Management, and Financial Markets, 15(2), 23-29.

4. Datta, S., Iskandar-Datta, M., \& Sharma, V. (2011). Product market pricing power, industry concentration and analysts' earnings forecasts. Journal of Banking \& Finance, 35(6), 1352-1366.

5. Durana, P., Michalkova, L., Privara, A., Marousek, J., \& Tumpach, M. (2021). Does the life cycle affect earnings management and bankruptcy? Oeconomia Copernicana, 12(2), 425-461.

6. Healy, P. M., \& Wahlen, J. M. (1999). A Review of the Earnings Management Literature and its Implications for Standard Setting. American Accounting Association, 365-383.

7. Hepworth, S R. (1953). Smoothing periodic income. The Accounting review, 28(1), 32.

8. Kliestik, T., Valaskova, K., Lazaroiu, G., Kovacova, M., \& Vrbka, J. (2020). Remaining Financially Healthy and Competitive: The Role of Financial Predictors. Journal of Competitiveness, 12(1), 74.

9. Kliestik, T., Valaskova, K., Nica, E., Kovacova, M., \& Lazaroiu, G. (2020). Advanced methods of earnings management: monotonic trends and change-points under spotlight in the Visegrad countries. Oeconomia Copernicana, 11(2), 371-400.

10. Management mania. (2015, June 30). Us Gaap. https://managementmania.com/sk/usgaap 
11. Management mania (2016, May 25). IAS-IFRS. https://managementmania.com/sk/iasifrs

12. Popescu, K. C., \& Olah, J. (2020). Use of the Bland-Altman plot for graphical demonstration of results in the sharing economy, Ekonomicko-manazerske spektrum, 14(2), 90-99.

13. Savova, K. (2021). Variable application of accounting standards - current aspects, Ekonomicko-manazerske spektrum, 15(1), 111-122.

14. Sedlak, M. (1997). Manažment, Bratislava: Elita.

15. Siekelova, A., Belas, J., Podhorska, I., Durana, P. (2021). Accrual-Based Earnings Management: A Case Study in V4 Focusing on Mining And Quarrying Sector. Acta Montanastica, Slovaca, 26(1), 70-83.

16. Strakova, L., \& Michalkova, L. (2020). Verification of Earnings Management in Slovak Enterprises using Teoh, Welch and Wong model. Hradec Economic Days, 733-739.

17. Tuovila, A. (2020, October 18). Earnings management. Investopedia https://www.investopedia.com/terms/e/earnings-management.asp

18. Vagner, L., Valaskova, K., Durana, P., \& Lazaroiu, G. (2021). Earnings management: A bibliometric analysis. Economics and Sociology, 14(1), 249-262. 